\title{
A chromatography-free and aqueous waste-free process for thioamide preparation with Lawesson's reagent
}

\author{
Ke Wu ${ }^{\ddagger}$, Yichen Ling ${ }^{\ddagger}$, An Ding, Liqun Jin*, Nan Sun, Baoxiang Hu, Zhenlu Shen \\ and Xinquan $\mathrm{Hu}^{*}$
}

Open Access

\author{
Full Research Paper \\ Address: \\ College of Chemical Engineering, Zhejiang University of Technology, \\ Hangzhou 310032, P.R. China

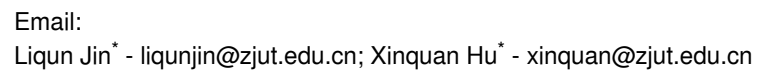

\author{
Beilstein J. Org. Chem. 2021, 17, 805-812. \\ https://doi.org/10.3762/bjoc.17.69 \\ Received: 05 November 2020 \\ Accepted: 26 February 2021 \\ Published: 09 April 2021 \\ Associate Editor: L. Vaccaro \\ (C) 2021 Wu et al.; licensee Beilstein-Institut. \\ License and terms: see end of document.
}

\begin{abstract}
After completing the thio-substitution with Lawesson's reagent, ethanol was found to be effective in the decomposition of the inherent stoichiometric six-membered-ring byproduct from the Lawesson's reagent to a highly polarized diethyl thiophosphonate. The treatment significantly simplified the following chromatography purification of the desired thioamide in a small scale preparation. As scaling up the preparation of two pincer-type thioamides, we have successfully developed a convenient process with ethylene glycol to replace ethanol during the workup, including a traditional phase separation, extraction, and recrystallization. The newly developed chromatography-free procedure did not generate P-containing aqueous waste, and only organic effluents were discharged. It is believed that the optimized procedure offers the great opportunity of applying the Lawesson's reagent for various thio-substitution reactions on a large scale.
\end{abstract}

\section{Introduction}

The transformation of a carbonyl into a thiocarbonyl group is one of the most important reactions in organic synthetic chemistry [1]. Lawesson's reagent (LR) is widely applied in this transformation, as well as for the syntheses of various sulfurcontaining heterocyclic compounds [2-5]. Although LR is a powerful, mild and versatile thionation reagent, the workup procedures of reactions involving this reagent have received quite a few negative comments [6-10]. The reason for this is that an inherent six-membered ring structure A (Figure 1) is formed from the LR upon thio-substitution [11-13]. It has been observed that the polarity of compound $\mathbf{A}$ is generally similar to the desired products, thus making the purification of the desired products by extraction operations less efficient. Therefore, the purification is rather difficult and usually a separation by careful column chromatography is necessary because of both the similar polarity and the stoichiometric amount of the formed compound A. With regard to this, the use of LR was always limited to small-scale preparations $[6,8]$. 


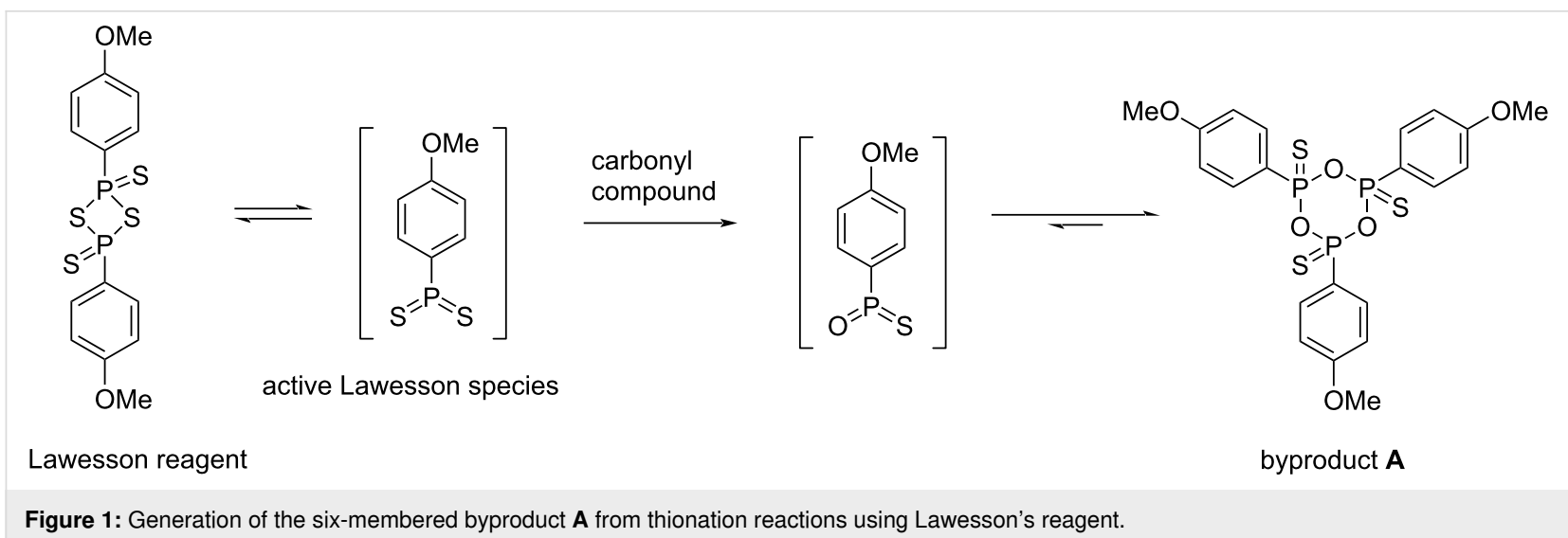

Other than the exploration of potential surrogates of LR for the thionation reactions, considerable efforts have been devoted to the improvement of the workup procedures of these reactions. For example, Soós and co-workers introduced perfluoroalkylated derivatives of LR, which simplified the product isolation via a fluorous reversed-phase solid extraction technique $[9,10]$. This method with long perfluorinated alkyl chains is attractive in parallel synthesis and also in high-throughput biological screening. However, both the modified LR and the fluorous solvents are rather expensive and not practical for scaling up. Besides, basic aqueous solutions were utilized as well in the work-up process and it was believed that the compound $\mathbf{A}$ was converted to a water-soluble thiophosphonate (Figure 2) [14-16]. Although this operation simplified the work-up procedure and allowed a scaled up chromatography-free purification, it generated quite large amounts of P-containing aqueous waste. The P-containing aqueous waste is unfavorable during the scaling up because of the difficult treatment in the downstream and also because it is one of the sources of eutrophication. Therefore, optimizing the work-up process of LR-mediated thionation reactions is greatly appealing for potential large-scale preparations.
Thioamides are highly attractive molecules in pharmaceuticals, agrochemicals, electronic chemicals, and materials sciences [17-27]. In coordination chemistry, pincer-type ligands containing a thioamide motif were shown to exhibit incomparable chelating ability towards selected transition metals, and the corresponding complexes were applied in various areas such as chemical-sensor materials, tunable redox-potential complexes, polymer hybrid luminescence materials, building blocks for multinuclear complexes, and as catalysts for cross-coupling reactions [28-35]. The thio-substitution of amides with LR is an efficient and straightforward method, because the amide substrates and LR are readily available and the reactions are easily operated [8,9,36-40]. With thio-substitution of amides as a model, we herein reported an efficient work-up procedure of applying LR by utilizing ethylene glycol to decompose the compound A (Figure 2). With a combination of some usual operations, such as, phase separation, extraction and crystallization, the desired thioamide products were efficiently obtained in excellent yields.

\section{Results and Discussion}

Our initial exploration began with the thio-substitution of $N$-phenylbenzamide (1a) with LR in toluene at reflux (Table 1).<smiles></smiles><smiles>COc1ccc(P2(=S)OP(=S)(c3ccc(OC)cc3)OP(=S)(c3ccc(OC)cc3)O2)cc1</smiles>

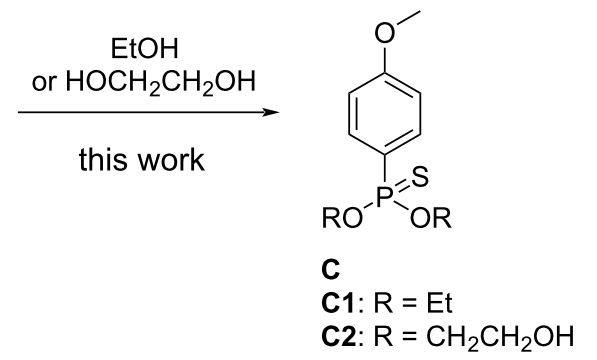

Figure 2: Work-up procedure for the reaction with LR. 
After completing the reaction, the solutions were split and treated with different additives at various temperatures in order to identify a reagent that efficiently decomposes compound $\mathbf{A}$ [41]. $\mathrm{MeOH}$ and $\mathrm{EtOH}$ were initially tested. The experimental results showed that $\mathrm{MeOH}$ can't fully decompose compound $\mathbf{A}$ in a temperature range between $40{ }^{\circ} \mathrm{C}$ to reflux, either after the removal of toluene or not. To our delight, EtOH worked well at reflux temperature and a new spot with a much higher polarity was observed on the TLC plate. With a mixed solvent of ethyl acetate/petroleum ether 1:3 as the eluent, the $R_{\mathrm{f}}$ of compound $\mathbf{A}$ was around 0.5 , while the $R_{\mathrm{f}}$ of the newly generated compound was at around 0.05 either from $\mathrm{MeOH}$ or $\mathrm{EtOH}$ treatment. Later, the new compound obtained by EtOH treatment was assigned as diethyl ( $p$-methoxyphenyl)thiophosphonate (C1) via GC-MS and confirmed by GC-TOF [42]. The change in the polarity of the byproduct after $\mathrm{MeOH}$ or EtOH treatment indicated that the separation by column chromatography could be simplified in a small-scale preparation. Indeed, with this improvement, various thioamides were conveniently synthesized and isolated in good to excellent yields after column chromatography (Table 1).

Although the synthesis of the thioamides at a $1 \mathrm{mmol}$ scale was successful, the required purification by column chromatography is a major drawback for reactions at a larger scale. All attempts to isolate the desired product from the reaction mix- ture after ethanol treatment, e.g., by solvent extraction/phase separation using solvents of various polarity or even with an aqueous workup failed and showed that compound $\mathbf{C 1}$ was well distributed in most solvents and acted as a polar solvent component. Although less polar solvents, such as heptane, reduced the amount of compound $\mathbf{C 1}$, however, they also failed to dissolve the desired thioamide product. Water as the solvent could partially extract compound $\mathbf{C 1}$, but the aqueous phase contained some product, too. Moreover, an aqueous workup after the EtOH treatment is regarded problematic because of the produced P-containing aqueous waste and this two-step treatment procedure was not as efficient as the direct workup with a saturated aqueous $\mathrm{NaHCO}_{3}$ solution [15]. With the above observations, we reckoned that converting compound $\mathbf{A}$ to a more polar derivative could probably be a breakthrough. As common knowledge, the more polarized alcohols over EtOH are those diols or polyols, while $\mathrm{MeOH}$ was previously ruled out. Ethylene glycol, a basic chemical and the simplest diol, is slightly soluble in toluene and attracted our interest. Both, its strong polarity and layering ability suggested that ethylene glycol may be an ideal choice.

Therefore, after completion of the thio-substitution reaction of 1e $(0.20 \mathrm{~mol})$ with LR (0.102 mol, Figure 3$)$, excess ethylene glycol was added to decompose compound $\mathbf{A}$ following the same procedure as described above for the EtOH treatment. To

Table 1: Synthesis of thioamides ${ }^{\text {a }}$.<smiles>[R]C(=O)Nc1cccc([R])c1</smiles>

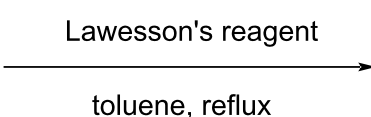

toluene, reflux

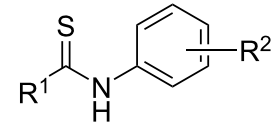

2

\begin{tabular}{|c|c|c|c|c|c|}
\hline \multirow[t]{2}{*}{ entry } & \multicolumn{3}{|c|}{ substrate } & \multirow[t]{2}{*}{ product 2} & \multirow[t]{2}{*}{ yield $(\%)^{b}$} \\
\hline & $\mathrm{R}^{1}$ & $\mathrm{R}^{2}$ & 1 & & \\
\hline 1 & $\mathrm{Ph}$ & $\mathrm{H}$ & $1 a$ & $2 a$ & 85 \\
\hline 2 & $4-\mathrm{MeC}_{6} \mathrm{H}_{4}$ & $\mathrm{H}$ & $1 b$ & $2 b$ & 79 \\
\hline 3 & $4-\mathrm{BrC}_{6} \mathrm{H}_{4}$ & $\mathrm{H}$ & $1 c$ & $2 c$ & 79 \\
\hline 4 & $4-t-\mathrm{BuC}_{6} \mathrm{H}_{4}$ & $\mathrm{H}$ & $1 d$ & $2 d$ & 76 \\
\hline 5 & $\mathrm{Ph}$ & $4-\mathrm{Me}$ & $1 e$ & $2 e$ & 82 \\
\hline 6 & $\mathrm{Ph}$ & $4-\mathrm{Cl}$ & $1 f$ & $2 f$ & 92 \\
\hline 7 & $\mathrm{Ph}$ & $4-\mathrm{Br}$ & $1 \mathrm{~g}$ & $2 g$ & 84 \\
\hline 8 & $\mathrm{Ph}$ & $4-1$ & $1 \mathrm{~h}$ & $2 \mathrm{~h}$ & 78 \\
\hline 9 & $\mathrm{Ph}$ & $3-\mathrm{Cl}$ & $1 \mathbf{i}$ & $2 \mathbf{i}$ & 75 \\
\hline 10 & $\mathrm{PhCH}_{2}$ & $\mathrm{H}$ & $1 \mathbf{j}$ & $2 \mathrm{j}$ & 70 \\
\hline 11 & $t-\mathrm{Bu}$ & $\mathrm{H}$ & $1 \mathrm{k}$ & $2 k$ & 76 \\
\hline
\end{tabular}

aReaction conditions: 1 (1 mmol), LR $(0.55 \mathrm{mmol})$, toluene $(4 \mathrm{~mL})$, reflux, $4 \mathrm{~h}$, then $2 \mathrm{~mL}$ EtOH, reflux, $2 \mathrm{~h}$; bisolated yields after column chromatography. 
<smiles>Cc1ccc(NC(=O)c2ccccc2)cc1</smiles>

$1 \mathrm{e}(0.2 \mathrm{~mol})$
1) Lawesson's reagent toluene, reflux, $2.5 \mathrm{~h}$

2) ethylene glycol/ $/ \mathrm{H}_{2} \mathrm{O}$ $95^{\circ} \mathrm{C}, 3.5 \mathrm{~h}$

3) toluene/heptane recrystallization<smiles>Cc1ccc(NC(=S)c2ccccc2)cc1</smiles>

2e, yield: $79 \%$

Figure 3: Modified process for the synthesis of $2 \mathrm{e}$ via phase separation.

our surprise, the decomposition was much slower as expected (TLC monitoring, see Supporting Information File 1). It was assumed that the ring-opening could be influenced by water or by the in situ-generated thiophosphonic acid. Thus, in addition to ethylene glycol $1.0 \mathrm{~mL}$ of water was added to the mixture and we were pleased to find that compound A smoothly decomposed at $95{ }^{\circ} \mathrm{C}$ in $3.5 \mathrm{~h}$. With the decline of compound $\mathbf{A}$ in the toluene layer, a new compound $\mathbf{C 2}$ emerged. It was also noticed that the $\mathrm{pH}$ value of the ethylene glycol layer was about 2-3. Thus, we reckoned that the assumed byproduct $\mathbf{C} 2$ was further decomposed to the thiophosphonic acid which is well soluble in ethylene glycol. After phase separation at $\approx 50{ }^{\circ} \mathrm{C}$, the ethylene glycol phase was back-extracted with toluene. The cooled toluene layers were treated with activated carbon and filtered. Then, toluene and other potential volatiles were removed, the residue crystallized from a toluene and heptane solvent mixture to afford $36.0 \mathrm{~g}$ (97\%) of the desired thioamide $2 \mathrm{e}$ as yellow crystalline solid.

With the proof that ethylene glycol can efficiently decompose compound $\mathbf{A}$ and simplify the work-up of the reaction with LR, this newly developed method was extended to synthesize two pincer ligands, $N^{2}, N^{6}$-di(n-butyl)pyridine-2,6-bis(carbothioamide) (4, Scheme 1) and $N^{2}, N^{6}$-bis(2,4,6-trimethylphenyl)pyridine-2,6-bis(carbothioamide) (6, Scheme 2) $[34,35,43,44]$. With a slight excess of LR, the diamide substrate 3 underwent thio-substitution in refluxing toluene for $2.5 \mathrm{~h}$, as monitored by TLC. After cooling of the reaction mixture, $100 \mathrm{~mL}$ of ethylene glycol containing $1.0 \mathrm{~mL}$ of water were added and the mixture stirred at $95{ }^{\circ} \mathrm{C}$ (oil bath) for $5 \mathrm{~h}$. Then, the mixture was allowed to cool to about $50{ }^{\circ} \mathrm{C}$ and transferred into a separation funnel for phase separation. The lower ethylene glycol phase was separated and extracted with additional $50 \mathrm{~mL}$ of toluene. The combined toluene layers were then treated with $3.1 \mathrm{~g}$ of activated carbon (10 wt \% of theoretical product) at room temperature. After filtration, the yellowcolored toluene solution was concentrated and the residue recrystallized from $75 \% \mathrm{EtOH} /$ water to afford $26.1 \mathrm{~g} \mathrm{(84 \% )}$ of the desired product 4 as yellow crystalline solid.

Because of a relative lower solubility and the higher molecular weight of diamide substrate $\mathbf{5}$, a longer time for the reaction with LR was essential for the completion of the reaction according to TLC monitoring. Following the similar workup procedure as described for compound $\mathbf{4}$, the resulting crude product was recrystallized from toluene to afford the product as brightyellow crystalline solid in $91 \%$ yield. The overall preparation of the pincer-type compound $\mathbf{6}$ is shown in Scheme 2.

As can be seen from Scheme 2, it is clear that the modified process only discharged organic wastes (toluene, and toluene/ heptane mixture), C2/ethylene glycol mixture, along with some waste of activated carbon [45].

\section{Conclusion}

In conclusion, we have developed a highly efficient process for the workup of thio-substitution reactions with Lawesson's reagent. In the newly developed procedure, ethylene glycol played a crucial role in the chromatography-free and avoiding P-containing aqueous waste workup procedure. With the preparation of a range of thioamides as examples, the ethylene glycol treatment allowed the work-up process involving phase separation, back-extraction, activated carbon treatment, and final recrystallization from a proper solvent. Parts of the recovered<smiles>CCCCNC(=O)c1cccc(C(=O)NCCCC)n1</smiles>

$3(0.1 \mathrm{~mol})$
1) Lawesson's reagent toluene, reflux, $2.5 \mathrm{~h}$

2) ethylene glycol/ $/ \mathrm{H}_{2} \mathrm{O}$ $95^{\circ} \mathrm{C}, 5 \mathrm{~h}$

3) $75 \% \mathrm{EtOH} / \mathrm{H}_{2} \mathrm{O}$ recrystallization<smiles>CCCCNC(=S)c1cccc(C(=S)NCCCC)n1</smiles>

4 yield: $84 \%$ 
<smiles>Cc1cc(C)c(NC(=O)c2cccc(C(=O)Nc3c(C)cc(C)cc3C)n2)c(C)c1</smiles>

$5(0.1 \mathrm{~mol})$
1) Lawesson's reagent toluene, reflux, $8 \mathrm{~h}$

2) ethylene glycol/ $\mathrm{H}_{2} \mathrm{O}$ $95^{\circ} \mathrm{C}, 7.5 \mathrm{~h}$

3) recrystallization from toluene<smiles>Cc1cc(C)c(NC(=S)c2cccc(C(=S)Nc3c(C)cc(C)cc3C)n2)c(C)c1</smiles>

6 yield: $91 \%$

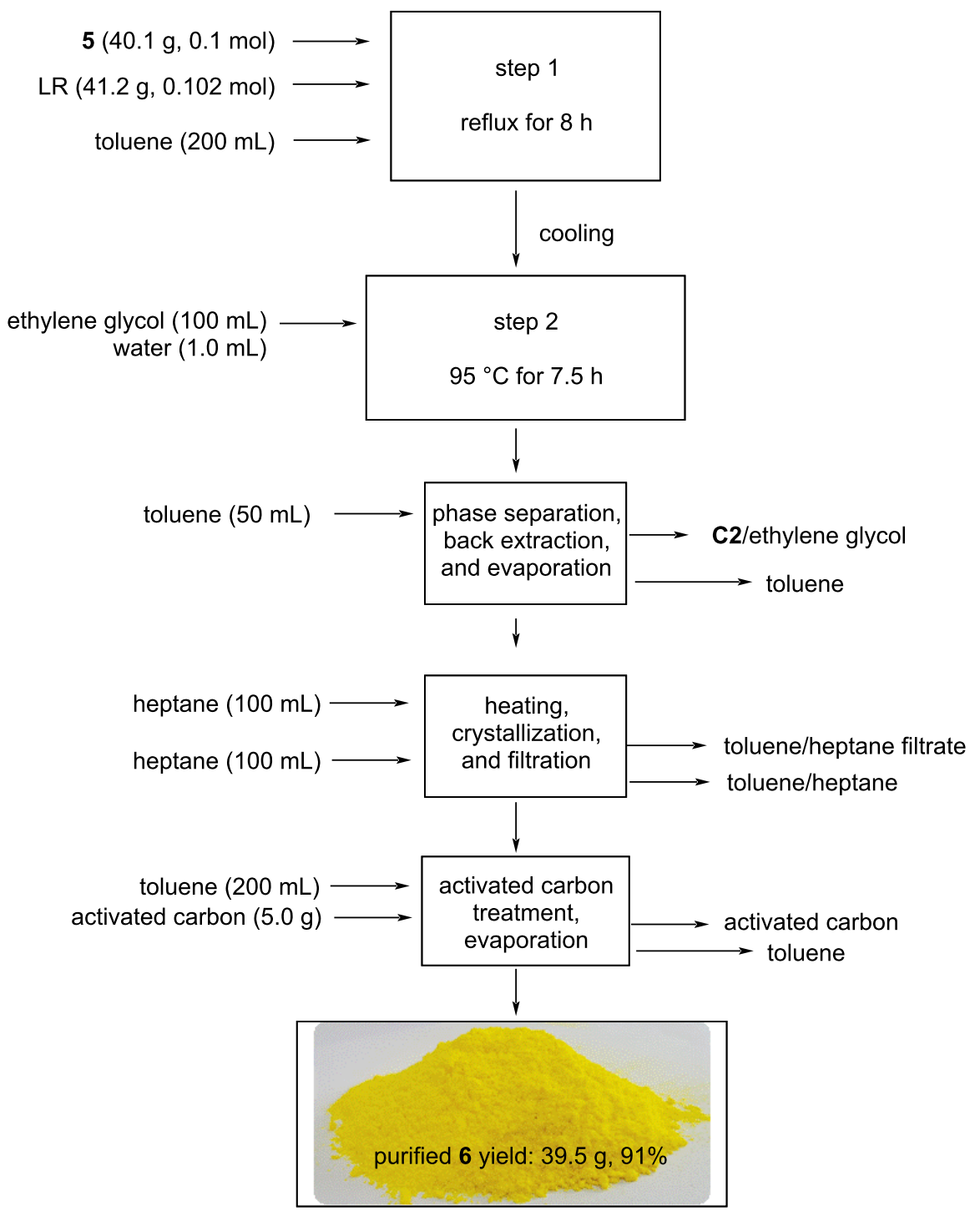

Scheme 2: Modified process for the synthesis of pincer-type ligand 6.

solvent could be reused and the effluent was also reduced. The improved procedure is believed to be suitable for the large-scale preparations with the application of Lawesson's reagent.

\section{Experimental}

General

The NMR spectra were recorded on a $400 \mathrm{MHz}, 500 \mathrm{MHz}$, and $600 \mathrm{MHz}$ spectrometer in deuterated solvents using tetramethyl- silane (TMS) as an internal standard. Chemical shifts were reported in parts per million (ppm, $\delta$ ) downfield from TMS. The following abbreviations were used to explain the multiplicities: $\mathrm{s}=$ singlet, $\mathrm{d}=$ doublet, $\mathrm{t}=$ triplet, $\mathrm{q}=$ quartet, $\mathrm{m}=$ multiplet, br $=$ broad. The structures of compounds $\mathbf{2 a - 1}$ were confirmed by comparison with reference data. Melting points were determined on a Büchi M-565 apparatus. All reagents were obtained from commercial suppliers and used without further purifica- 
tion. The reactions were monitored by thin-layer chromatography. Column chromatography was performed using silica gel (300-400 mesh). Amides 1a-l were prepared following the reported procedure [46].

\section{Typical procedure for the synthesis of thioamide 2 (1 mmol scale)}

A mixture of amide $\mathbf{1}(1.0 \mathrm{mmol})$ and Lawesson's reagent $(0.60 \mathrm{mmol})$ was refluxed in toluene $(4 \mathrm{~mL})$. The reaction progress was monitored by TLC until full consumption of the starting amide was observed. To the cooled mixture was added EtOH ( $2 \mathrm{~mL}$, excess) and the resulting mixture was heated at reflux for $2 \mathrm{~h}$. Then, the volatiles were removed under reduced pressure. The residue was diluted with ethyl acetate followed by aqueous workup. The organic phase was dried over anhydrous $\mathrm{MgSO}_{4}$. The solvent was removed under reduced pressure. The reside was purified by silica gel column chromatography using petroleum ether/ethyl acetate as the eluent to afford the desired thioamide 2.

\section{Synthesis of $N^{2}, N^{6}$-di ( $n$-butyl)pyridine-2,6-(carbo- thioamide) (3) [34]}

To a $500 \mathrm{~mL}$ four-necked flask were added $50.1 \mathrm{~g}$ of pyridine2,6-dicarboxylic acid (0.3 mol), $1 \mathrm{~mL}$ of DMF and $55 \mathrm{~mL}$ of $\mathrm{SOCl}_{2}$. The mixture was heated to $80{ }^{\circ} \mathrm{C}$ to get a clear solution and stirred for $30 \mathrm{~min}$. Then, $\mathrm{SOCl}_{2}$ was removed in vacuum and the crude acyl chloride was dissolved in $50 \mathrm{~mL}$ of toluene. To a $1 \mathrm{~L}$ flask were added $48 \mathrm{~g}$ of $n$-butylamine $(0.66 \mathrm{~mol})$, $126 \mathrm{~g}$ of $\mathrm{NaHCO}_{3}(1.5 \mathrm{~mol}), 400 \mathrm{~mL}$ of toluene and $100 \mathrm{~mL}$ of water. At $0{ }^{\circ} \mathrm{C}$, the above acyl chloride in toluene was added slowly and the mixture was stirred for $20 \mathrm{~min}$ at $0{ }^{\circ} \mathrm{C}$ and allowed to reach room temperature over $30 \mathrm{~min}$. After filtration, the filter cake was washed with water and recrystallized from EtOH $(200 \mathrm{~mL}) / \mathrm{H}_{2} \mathrm{O}(90 \mathrm{~mL})$ to afford the desired diamide 3 in $70 \%$ yield as white solid. $\mathrm{Mp} 155.2-158.0{ }^{\circ} \mathrm{C} ;{ }^{1} \mathrm{H}$ NMR $\left(600 \mathrm{MHz}, \mathrm{CDCl}_{3}\right) \delta 8.33(\mathrm{~d}, J=7.8 \mathrm{~Hz}, 2 \mathrm{H}), 8.03-7.94(\mathrm{~m}$, $3 \mathrm{H}), 3.48-3.42(\mathrm{~m}, 4 \mathrm{H}), 1.63-1.55(\mathrm{~m}, 4 \mathrm{H}), 1.42-1.32(\mathrm{~m}, 4 \mathrm{H})$, 0.93-0.89 (m, 6H); $\left.{ }^{13} \mathrm{C} \mathrm{NMR} \mathrm{(150} \mathrm{MHz,} \mathrm{CDCl}_{3}\right) \delta 163.7$, $149.1,139.1,125.0,39.5,31.9,20.3,13.9$.

\section{Synthesis of $N^{2}, N^{6}$-bis(2,4,6-trimethylphenyl)pyri- dine-2,6-(carbothioamide) (5) [34]}

Following a similar procedure as described for diamide $\mathbf{3}$, the desired diamide $\mathbf{5}$ was obtained from the reaction of pyridine2,6-dicarboxylic acid (50.1 g, $0.3 \mathrm{~mol}$ ) and 2,4,6-trimethylaniline $(89.2 \mathrm{~g}, 0.66 \mathrm{~mol})$ in $92 \%$ yield as white solid. $\mathrm{Mp}$ 191.5-193.3 ${ }^{\circ} \mathrm{C}$; ${ }^{1} \mathrm{H}$ NMR (600 MHz, $\left.\mathrm{CDCl}_{3}\right) \delta 9.05(\mathrm{~s}, 1 \mathrm{H})$, $8.51(\mathrm{~d}, J=7.8 \mathrm{~Hz}, 2 \mathrm{H}), 8.15(\mathrm{t}, J=7.8 \mathrm{~Hz}, 1 \mathrm{H}), 6.96(\mathrm{~s}, 4 \mathrm{H})$, $2.31(\mathrm{~s}, 6 \mathrm{H}), 2.26(\mathrm{~s}, 12 \mathrm{H}) ;{ }^{13} \mathrm{C} \mathrm{NMR}\left(150 \mathrm{MHz}, \mathrm{CDCl}_{3}\right) \delta$ $161.8,149.0,139.5,137.3,135.1,130.7,129.2,125.7,77.4$, $77.2,77.0,21.1,18.5$.
Procedure for the synthesis of $N$ - $(p$-methylphenyl)benzothioamide (2e) (0.2 mol scale) [47] To a $500 \mathrm{~mL}$ three-necked flask, $42.3 \mathrm{~g}$ of $N$ - $p$-methylphenylbenzamide $(0.20 \mathrm{~mol}), 42.0 \mathrm{~g}$ of Lawesson's reagent $(0.104 \mathrm{~mol})$, and $200 \mathrm{~mL}$ of toluene were added. The mixture was heated to reflux under a nitrogen atmosphere. The reaction was completed in $3 \mathrm{~h}$ by TLC monitoring. Then, to the cooled mixture, were added $100 \mathrm{~mL}$ of ethylene glycol (excess), together with $1.0 \mathrm{~mL}$ of water, and the resulting mixture was stirred at $95{ }^{\circ} \mathrm{C}$. TLC monitoring of the toluene layer showed that the byproduct A from Lawesson's reagent had disappeared after $3.5 \mathrm{~h}$. The slightly cooled mixture was transferred to a separation funnel. The ethylene glycol layer was left standing overnight. The formed precipitate was collected, combined with the toluene phase and heated to form a clear solution. Then, $50 \mathrm{~mL}$ of heptane were added and the resulting solution was gradually cooled. The precipitation was observed at $65^{\circ} \mathrm{C}$ and stirring was continued until the temperature reached $20{ }^{\circ} \mathrm{C}$. After filtration, the solid was washed with heptane $(50 \mathrm{~mL})$ and dried to afford $36.0 \mathrm{~g}$ of the desired thioamide product $2 \mathrm{e}(79 \%)$ as bright yellow crystalline solid. Mp $128.5-130.1{ }^{\circ} \mathrm{C} ;{ }^{1} \mathrm{H}$ NMR (500 MHz, DMSO- $\left.d_{6}\right) \delta 11.67(\mathrm{~s}, 1 \mathrm{H}), 7.82(\mathrm{~d}, J=7.6 \mathrm{~Hz}, 2 \mathrm{H})$, $7.69(\mathrm{~d}, J=7.6 \mathrm{~Hz}, 2 \mathrm{H}), 7.52(\mathrm{t}, J=7.0 \mathrm{~Hz}, 1 \mathrm{H}), 7.46(\mathrm{t}, J=$ $7.6 \mathrm{~Hz}, 2 \mathrm{H}), 7.24(\mathrm{~d}, J=7.6 \mathrm{~Hz}, 2 \mathrm{H}), 2.32(\mathrm{~s}, 3 \mathrm{H}) ;{ }^{13} \mathrm{C} \mathrm{NMR}$ $\left(125 \mathrm{MHz}, \mathrm{DMSO}-d_{6}\right) \delta 197.4,142.7,137.6,135.7,130.7$, 129.0, 128.1, 127.5, 124.2, 20.8 .

Procedure for the synthesis of $N^{2}, N^{6}$-di $(n$-butyl)pyridine-2,6-bis(carbothioamide) (4) (0.1 mol scale) [34] To a $500 \mathrm{~mL}$ three-necked flask, $27.7 \mathrm{~g}$ of $N^{2}, N^{6}-\operatorname{di}(n-$ butyl)pyridine-2,6-(carbothioamide) $(3,0.10 \mathrm{~mol}), 42.4 \mathrm{~g}$ Lawesson's reagent $(0.0525 \mathrm{~mol})$, and $150 \mathrm{~mL}$ of toluene were added. The mixture was heated to reflux under a nitrogen atmosphere. The reaction was completed in $2.5 \mathrm{~h}$ by TLC monitoring. Then, to the cooled mixture were added $100 \mathrm{~mL}$ of ethylene glycol (excess), together with $1.0 \mathrm{~mL}$ of water, and the resulting mixture was stirred at $95{ }^{\circ} \mathrm{C}$. TLC monitoring of the toluene layer showed that the byproduct A from Lawesson's reagent had disappeared after $5 \mathrm{~h}$. The slightly cooled mixture was transferred to a separation funnel. The ethylene glycol layer and $50 \mathrm{~mL}$ of toluene were transferred back to the flask and stirred at $95{ }^{\circ} \mathrm{C}$ (oil bath) for $30 \mathrm{~min}$. The combined toluene layers were treated with $3.1 \mathrm{~g}$ of activated carbon (10 wt \% of the theoretical amount of dithioamide 4). After filtration, the solid was washed with toluene. The solvent was removed under reduced pressure and the yellowish residue was recrystallized from $190 \mathrm{~mL}$ of $75 \% \mathrm{EtOH}$ to afford $26.1 \mathrm{~g}$ of the dithioamide $4(84 \%)$ as a yellowish crystalline solid. $\mathrm{Mp} 72.2-74.5{ }^{\circ} \mathrm{C}$; ${ }^{1} \mathrm{H} \mathrm{NMR}\left(600 \mathrm{MHz}, \mathrm{CDCl}_{3}\right) \delta 9.44(\mathrm{~s}, 2 \mathrm{H}), 8.78(\mathrm{~d}, J=7.8 \mathrm{~Hz}$, $2 \mathrm{H}), 7.94(\mathrm{t}, J=7.8 \mathrm{~Hz}, 1 \mathrm{H}), 3.91-3.86(\mathrm{~m}, 4 \mathrm{H}), 1.84-1.77(\mathrm{~m}$, $4 \mathrm{H}), 1.55-1.48(\mathrm{~m}, 4 \mathrm{H}), 1.02(\mathrm{t}, J=7.4 \mathrm{~Hz}, 6 \mathrm{H}) ;{ }^{13} \mathrm{C} \mathrm{NMR}$ 
$\left(150 \mathrm{MHz}, \mathrm{CDCl}_{3}\right) \delta 190.4,149.6,138.4,127.3,45.9,30.2$, $20.5,13.9$.

Procedure for the synthesis of $N^{2}, N^{6}$-bis(2,4,6-trimethylphenyl)pyridine-2,6-bis(carbothioamide) (6) (0.1 mol scale) [34]

To a $500 \mathrm{~mL}$ three-necked flask $40.1 \mathrm{~g}$ of $N^{2}, N^{6}$-bis(2,4,6-trimethylphenyl)pyridine-2,6-(carbothioamide) $(\mathbf{5}, 0.10 \mathrm{~mol})$, $41.2 \mathrm{~g}$ of Lawesson's reagent $(0.051 \mathrm{~mol})$, and $200 \mathrm{~mL}$ of toluene were added. The mixture was heated to reflux under a nitrogen atmosphere. TLC monitoring showed that there still existed some amide-thioamide intermediate after $5 \mathrm{~h}$ and heating was continued for another $3 \mathrm{~h}$. Afterwards, TLC monitoring showed that the amide-thioamide had nearly disappeared. Then, to the cooled mixture, were added $100 \mathrm{~mL}$ of ethylene glycol (excess), together with $1.0 \mathrm{~mL}$ of water and the resulting mixture was stirred at $95{ }^{\circ} \mathrm{C}$. TLC monitoring of the toluene layer showed that the byproduct A of the Lawesson's reagent had disappeared after $7.5 \mathrm{~h}$. The slightly cooled mixture was transferred to a separation funnel. The toluene layer was separated, and the ethylene glycol layer and $50 \mathrm{~mL}$ of toluene were transferred back to the flask and stirred at $95{ }^{\circ} \mathrm{C}$ (oil bath) for $30 \mathrm{~min}$. The toluene layers were combined, part of the solvent removed under reduced pressure and the remaining solution was heated to reflux and diluted with $100 \mathrm{~mL}$ of heptane. The solution remained clear during reflux. Then, the solution was cooled to precipitate the crystalline solid that was collected by filtration and washed with heptane $(100 \mathrm{~mL})$. Then, the solid was treated with $200 \mathrm{~mL}$ of toluene and $5.0 \mathrm{~g}$ of activated carbon at $80{ }^{\circ} \mathrm{C}$, followed by hot filtration. The filtrate was concentrated to afford $39.5 \mathrm{~g}$ of the desired dithioamide 6 (91\%) as brightyellow crystalline solid. Mp 190.5-193.6 ${ }^{\circ} \mathrm{C}$; ${ }^{1} \mathrm{H}$ NMR $\left(600 \mathrm{MHz}, \mathrm{CDCl}_{3}\right) \delta 10.71(\mathrm{~s}, 2 \mathrm{H}), 8.99$ (d, $\left.J=7.8 \mathrm{~Hz}, 2 \mathrm{H}\right)$, $8.07(\mathrm{t}, \mathrm{J}=7.8 \mathrm{~Hz}, 1 \mathrm{H}), 6.99(\mathrm{~s}, 4 \mathrm{H}), 2.33(\mathrm{~s}, 6 \mathrm{H}), 2.23$ (s, $12 \mathrm{H}) ;{ }^{13} \mathrm{C}$ NMR $\left(150 \mathrm{MHz}, \mathrm{CDCl}_{3}\right) \delta 190.8,149.4,138.7$, 138.5, 135.1, 133.4, 129.4, 128.0, 21.3, 18.3.

\section{Supporting Information}

\section{Supporting Information File 1}

NMR data for compounds 2-6 and thiophosphonic acid.

[https://www.beilstein-journals.org/bjoc/content/

supplementary/1860-5397-17-69-S1.pdf]

\section{Funding}

This work was supported by the National Natural Science Foundations of China (21972125 and 21773210) and the Fundamental Research Funds for the Provincial Universities of Zhejiang (RF-B2019005).

\section{ORCID ${ }^{\circledR} \mathrm{iDs}$}

Liqun Jin - https://orcid.org/0000-0002-9518-7423 Nan Sun - https://orcid.org/0000-0003-4108-5218

Xinquan Hu - https://orcid.org/0000-0001-8266-4086

\section{Preprint}

A non-peer-reviewed version of this article has been previously published as a preprint: https://doi.org/10.3762/bxiv.2020.126.v1

\section{References}

1. Murai, T. Top. Curr. Chem. 2018, 376, 31. doi:10.1007/s41061-018-0209-0

2. Jesberger, M.; Davis, T. P.; Barner, L. Synthesis 2003, 1929-1958. doi:10.1055/s-2003-41447

3. Ozturk, T.; Ertas, E.; Mert, O. Chem. Rev. 2007, 107, 5210-5278. doi:10.1021/cr040650b

4. Saeed, A.; Mehfooz, H.; Larik, F. A.; Faisal, M.; Channar, P. A. J. Asian Nat. Prod. Res. 2017, 19, 1114-1123. doi:10.1080/10286020.2017.1295229

5. Feng, M.; Tang, B.; Liang, S. H.; Jiang, X. Curr. Top. Med. Chem. 2016, 16, 1200-1216. doi:10.2174/1568026615666150915111741

6. Curphey, T. J. J. Org. Chem. 2002, 67, 6461-6473. doi:10.1021/jo0256742

7. Thomsen, I.; Clausen, K.; Scheibye, S.; Lawesson, S. O. Org. Synth. 1984, 62, 158-164. doi:10.15227/orgsyn.062.0158

8. Larik, F. A.; Saeed, A.; Muqadar, U.; El-Seedi, H.; Faisal, M.; Channar, P. A.; Mehfooz, H. Phosphorus, Sulfur Silicon Relat. Elem. 2017, 192, 490-502. doi:10.1080/10426507.2016.1259236

9. Kaleta, Z.; Makowski, B. T.; Soós, T.; Dembinski, R. Org. Lett. 2006, 8, 1625-1628. doi:10.1021/ol060208a

10. Kaleta, Z.; Tárkányi, G.; Gömöry, Á.; Kálmán, F.; Nagy, T.; Soós, T. Org. Lett. 2006, 8, 1093-1095. doi:10.1021/ol0529849

11. Pedersen, B. S.; Scheibye, S.; Nilsson, N. H.; Lawesson, S.-O. Bull. Soc. Chim. Belg. 1978, 87, 223-228. doi:10.1002/bscb.19780870310

12. Wen, T.; Bau, R.; McKenna, C. E. J. Chem. Soc., Chem. Commun. 1991, 1223-1224. doi:10.1039/c39910001223

13. Gayen, K. S.; Chatterjee, N. Asian J. Org. Chem. 2020, 9, 508-528. doi:10.1002/ajoc.202000032

14. Anson, M. S.; Graham, J. P.; Roberts, A. J. Org. Process Res. Dev. 2011, 15, 649-659. doi:10.1021/op2000095

15. Li, Z.; Tang, X.; Jiang, Y.; Zuo, M.; Wang, Y.; Chen, W.; Zeng, X.; Sun, Y.; Lin, L. Green Chem. 2016, 18, 2971-2975. doi:10.1039/c6gc00566g

16. Fujieda, H.; Maeda, K.; Kato, N. Org. Process Res. Dev. 2019, 23 , 69-77. doi:10.1021/acs.oprd.8b00354

17. Hurd, R. N.; DeLaMater, G. Chem. Rev. 1961, 61, 45-86. doi:10.1021/cr60209a003

18. Velkov, Z. Bulg. Chem. Commun. 2003, 35, 227-230.

19. Jagodziński, T. S. Chem. Rev. 2003, 103, 197-228. doi:10.1021/cr0200015

20. Begum, R. A.; Powell, D.; Bowman-James, K. Inorg. Chem. 2006, 45, 964-966. doi:10.1021/ic051775h

21. Kanbara, T.; Okada, K.; Yamamoto, T.; Ogawa, H.; Inoue, T. J. Organomet. Chem. 2004, 689, 1860-1864. doi:10.1016/j.jorganchem.2004.03.003

22. Lee, H.-J.; Choi, Y.-S.; Lee, K.-B.; Park, J.; Yoon, C.-J. J. Phys. Chem. A 2002, 106, 7010-7017. doi:10.1021/jp025516e 
23. Zacharie, B.; Lagraoui, M.; Dimarco, M.; Penney, C. L.; Gagnon, L. J. Med. Chem. 1999, 42, 2046-2052. doi:10.1021/jm9900467

24. Tan, W.; Wang, C.; Jiang, X. Chin. J. Chem. 2019, 37, 1234-1238. doi:10.1002/cjoc.201900360

25. Wei, J.; Li, Y.; Jiang, X. Org. Lett. 2016, 18, 340-343. doi:10.1021/acs.orglett.5b03541

26. Tan, W.; Wei, J.; Jiang, X. Org. Lett. 2017, 19, 2166-2169. doi:10.1021/acs.orglett.7b00819

27. Tan, W.; Jänsch, N.; Öhlmann, T.; Meyer-Almes, F.-J.; Jiang, X. Org. Lett. 2019, 21, 7484-7488. doi:10.1021/acs.orglett.9b02784

28. Okamoto, K.; Kuwabara, J.; Kanbara, T. Chem. Lett. 2015, 44, 102-110. doi:10.1246/cl.140996

29. Aleksanyan, D. V.; Kozlov, V. A. Pincer Complexes with Thione Sulfur Donors. In The Privileged Pincer-Metal Platform: Coordination Chemistry \& Applications; van Koten, G.; Gossage, R., Eds.; Topics in Organometallic Chemistry, Vol. 54; 2016; pp 209-238. doi:10.1007/3418_2015_115

30. Kuwabara, J.; Munezawa, G.; Okamoto, K.; Kanbara, T. Dalton Trans. 2010, 39, 6255-6261. doi:10.1039/c002908d

31. Ogawa, Y.; Taketoshi, A.; Kuwabara, J.; Okamoto, K.; Fukuda, T.; Kanbara, T. Chem. Lett. 2010, 39, 385-387. doi:10.1246/cl.2010.385

32. Okamoto, K.; Yamamoto, T.; Akita, M.; Wada, A.; Kanbara, T. Organometallics 2009, 28, 3307-3310. doi:10.1021/om800894j

33. Hossain, M. A.; Lucarini, S.; Powell, D.; Bowman-James, K. Inorg. Chem. 2004, 43, 7275-7277. doi:10.1021/ic0489645

34. Liu, J.; Wang, H.; Zhang, H.; Wu, X.; Zhang, H.; Deng, Y.; Yang, Z.; Lei, A. Chem. - Eur. J. 2009, 15, 4437-4445. doi:10.1002/chem.200802238

35. Wang, H.; Liu, J.; Deng, Y.; Min, T.; Yu, G.; Wu, X.; Yang, Z.; Lei, A. Chem. - Eur. J. 2009, 15, 1499-1507. doi:10.1002/chem.200801860

36. Downer-Riley, N. K.; Jackson, Y. A. Tetrahedron 2008, 64, 7741-7744. doi:10.1016/j.tet.2008.06.023

37. Fuchibe, K.; Bando, M.; Takayama, R.; Ichikawa, J. J. Fluorine Chem. 2015, 171, 133-138. doi:10.1016/j.jluchem.2014.08.013

38. Zhang, G.; Liu, C.; Yi, H.; Meng, Q.; Bian, C.; Chen, H.; Jian, J.-X.; Wu, L.-Z.; Lei, A. J. Am. Chem. Soc. 2015, 137, 9273-9280. doi:10.1021/jacs.5b05665

39. Xu, Z.-M.; Li, H.-X.; Young, D. J.; Zhu, D.-L.; Li, H.-Y.; Lang, J.-P. Org. Lett. 2019, 21, 237-241. doi:10.1021/acs.orglett.8b03679

40. Henry, M. C.; Abbinante, V. M.; Sutherland, A. Eur. J. Org. Chem. 2020, 2819-2826. doi:10.1002/ejoc.202000014

41. Przychodzeń, W. Eur. J. Org. Chem. 2005, 2002-2014. doi:10.1002/ejoc.200400727

42. Trying to separate the compound $\mathrm{C} 1$ failed. The highly polar product obtained by column chromatography was finally confirmed to be thiophosphonic acid by ${ }^{1} \mathrm{H}$ NMR.

43. Liu, J.; Deng, Y.; Lin, C.; Lei, A. Chem. Sci. 2012, 3, 1211-1214. doi:10.1039/c2sc00888b

44. Suzuki, T.; Kajita, Y.; Masuda, H. Dalton Trans. 2014, 43, 9732-9739. doi:10.1039/c4dt00524d

45. In the current procedure, the phase separation and back extraction could not completely avoid a slight amount of ethylene glycol because due to solubility issues of the desired product that resulted in rapid precipitation. It should be noted that $\mathrm{EtOH}$ or aqueous $\mathrm{EtOH}$ was used as the recrystallization solvent, and the product contained co-crystallized solvent.

46. Chen, T.-T.; Wang, A.-E.; Huang, P.-Q. Org. Lett. 2019, 21 , 3808-3812. doi:10.1021/acs.orglett.9b01257
47. Do, N. T.; Tran, K. M.; Phan, H. T.; To, T. A.; Nguyen, T. T.; Phan, N. T. S. Org. Biomol. Chem. 2019, 17, 8987-8991. doi:10.1039/c9ob01751h

\section{License and Terms}

This is an Open Access article under the terms of the Creative Commons Attribution License (https://creativecommons.org/licenses/by/4.0). Please note that the reuse, redistribution and reproduction in particular requires that the author(s) and source are credited and that individual graphics may be subject to special legal provisions.

The license is subject to the Beilstein Journal of Organic Chemistry terms and conditions:

(https://www.beilstein-journals.org/bjoc/terms)

The definitive version of this article is the electronic one which can be found at: https://doi.org/10.3762/bjoc.17.69 